\title{
THE RELATIONSHIPS BETWEEN THE PROVIDING OF SELF-PROTECTIVE EQUIPMENT AND OCCUPATIONAL STRESS EVENTS OF HEALTH OFFICERS IN THE HANDLING OF COVID-19 IN KANDAI HEALTH CENTER
}

\author{
Noviati $^{1 *}$, Sitti Marya Ulva ${ }^{2}$ \\ ${ }^{1,2}$ Department of Public Health, Universitas Mandala Waluya \\ Kendari, Southeast Sulawesi Province, Indonesia
}

Corresponding Author : Noviati

Email : noviati.novy@gmail.com

\begin{abstract}
Background: The corona virus (covid-19) pandemic in Indonesia is still growing. Every week the number of infections of Covid-19 was 2,273 cases. Where as, 198 of them died and 164 people were treated. In fact, among them are healthy workers who help treat corona virus patients and become infected afterward. There was a shortage of personal protective equipment (PPE) for health workers in Southeast Sulawesi province, especially at Kendari City, Health Center Kandai. This makes health workers have to take turns wearing PPE if they want to do their job. Therefore, many health workers feel restless and do not want to carry out their duties if they are not provided with adequate PPE, because they will examine people or patients whose health status is not yet known. The purpose of this study is to analyze the relationship between the providing of self-protective equipment and occupational stress events of health officers in the handling of Covid-19 at Kandai health center.

Methods: This type of research is an analytic study with a cross-sectional approach. The sample in this study amounted to 58 people using the total sampling method.

Results: The results showed that there was a relationship between the provision of Personal Protective Equipment (PPE) with the incidence of work stress for health workers in handling covid19 at Kandai Health CenterKendari City, with the statistical test results being 18,322.

Conclusion: It is hoped that policy makers, especially the head of the Kandai Health Center, pay more attention to the safety and health of their employees, such as in the provision of PPE, and for health workers, especially at Kandai Health Center, to further improve the Covid-19 protocol that is applied to themselves and patients.
\end{abstract}

Keywords: Equipment, Work, Stress, Covid-19, Health Centre. 


\section{INTRODUCTION}

Occupational health and safety is an effort to ensure wholeness and perfection both physically and spiritually for every workforce in particular, and humans in general [1]. Health service facilities are required to provide health security guarantees for both health workers and the people they serve, because of the spread of an infectious disease currently being experienced, namely Covid-19.

Based on Law No.1 of 1970 concerning Work Safety, in particular Articles 9, 12, and 14 which states that managers or workplace leaders are obliged to provide personal protective equipment (PPE) for workers in the case that health workers and health workers are obliged to wear PPE appropriately and right. The provision and use of PPE is also very important in preventing the transmission of the corona virus (covid-19) and also in giving health workers a sense of security and confidence in carrying out their duties. However, if the provision of PPE is limited, it will cause anxiety for health workers because they feel that at any time they can be infected by the corona virus. This can make health workers experience work stress.

The corona virus (covid-19) pandemic in Indonesia is still growing. As of Sunday, the number of infections that have been confirmed positive for Covid-19 is 2,273. Of these, 198 of them died and 164 people managed to recover. The patients who died had different backgrounds. In fact, among them are healthy workers who help treat corona virus patients and become infected afterward. Among the recorded cases of death, at least 18 doctors have died due to Covid-19. The cases of the deaths of the front guards in the "war" against the epidemic raise questions about their security. There is a shortage of personal protective equipment (PPE) for health workers. Several reports have emerged suggesting that doctors and other medical staff have had to modify PPE with plastic raincoats to trash bags [2].

Health care providers have felt the limitations of PPE in various health agencies in Southeast Sulawesi province, especially at the Kendari City Health Center Kandai. This makes health workers have to take turns wearing PPE if they want to do their job. Therefore, many health workers feel restless and do not want to carry out their duties if they are not provided with adequate PPE, because they will examine people or patients whose health status is not yet known.

\section{METHODS}

This type of research is an analytical study with a cross-sectional approach, which means that research is conducted with positive risk factors and negative risk factors examined simultaneously.

The population in this study were all health workers who worked at the Kandai health center, amounting to 58 people. Because the population in this study was less than 100 , the sampling technique used total sampling, which amounted to 58 people and meet the following inclusion requirements: a. not on leave when the research was conducted; $b$. willing to be a respondent.

Data obtained from direct observations in the field using a questionnaire, processed by computerization, and then the results are presented in tabular form.

\section{RESULTS}

\section{Characteristics of respondents}

\section{a. Age}

Based on table 1 above, the most age group was in the 26 - 31 year ago group, namely 29 people $(50.0 \%)$ and the lowest was in the 50 - 55 year age group, namely 1 person $(1.7 \%)$. 


\section{b. Gender}

The data in table 3 shows that respondents at Kandai Health Center in Kendari City were dominated by female respondents, namely as many as 47 people $(81.0 \%)$ while male respondents were 11 people $(19.0 \%)$.

\section{Univariate Analysis}

Table 3 above shows that the highest percentage was in the non-stress category of as many as 41 people $(70.7 \%)$,

\section{a. Work Stress}

while the lowest was in the stress category of as many as 17 people (29.3\%).

\section{b. Provision of Personal Protective Equipment (PPE)}

Table 4 above shows that the highest percentage of the variable provision of PPE is in the sufficient category of 35 people $(60.3 \%)$, while the lowest is in the less category of 23 people (39.7\%).

\section{Bivariate Analysis}

Based on table 5 above, it shows that among 58 respondents there are 9 respondents $(39.1 \%)$ who think that the provision of PPE is categorized as insufficient but not stressful, 14 respondents $(60.9 \%)$ think that the provision of PPE is insufficient and stressful. Meanwhile, 32 respondents $(91.4 \%)$ thought that the provision of PPE was sufficient and not stressed and those who thought that the provision of PPE was sufficient but experienced stress were 3 respondents $(8.6 \%)$.

Chi-square statistical test results obtained the value of X2 count $=18.322$ and $\mathrm{X} 2$ table $=3.841$. Thus $\mathrm{X} 2$ count $>\mathrm{X} 2$ table, then $\mathrm{HO}$ is rejected and $\mathrm{Ha}$ is accepted and it is also known that the P-value $=0.000>\alpha=$ 0.05 means that there is a relationship between the provision of PPE with the incidence of work stress on health workers in handling covid-19at Kandai Health Center.

Table 1.

Respondents by Age Group at Kandai Health Center

\begin{tabular}{|c|c|c|c|}
\hline No. & Age (Year) & n & $\%$ \\
\hline 1. & $20-25$ & 12 & 20,7 \\
2. & $26-31$ & 29 & 50,0 \\
3. & $32-37$ & 9 & 15,5 \\
4. & $38-43$ & 5 & 8,6 \\
5. & $44-49$ & 2 & 3,4 \\
6. & $50-55$ & 1 & 1,7 \\
\hline \multicolumn{2}{|c|}{ Total } & 58 & 100 \\
\hline
\end{tabular}

Table 2

Distribution of Respondents by Gender at Kandai Health Centre

\begin{tabular}{|c|c|c|c|}
\hline No. & Gender & $\mathrm{n}$ & $\%$ \\
\hline 1. & Male & 11 & 19,0 \\
2. & Famale & 47 & 81,0 \\
\hline \multicolumn{2}{|c|}{ Total } & 58 & 100 \\
\hline
\end{tabular}


Table 3.

Distribution of Work Stress for Health Workers At Kandai Health Center

\begin{tabular}{|c|l|c|c|}
\hline No. & \multicolumn{1}{|c|}{ Work Stress } & $\mathrm{n}$ & $\%$ \\
\hline 1. & Don`t Stress & 41 & 70,7 \\
2. & Stress & 17 & 29,3 \\
\hline \multicolumn{2}{|c|}{ Total } & 58 & 100 \\
\hline
\end{tabular}

Table 4.

Distribution of Provision of Personal Protective Equipment (PPE) for

Health Officer at Kandai Health Center

\begin{tabular}{|c|l|c|c|}
\hline No. & \multicolumn{1}{|c|}{ Provision of PPE } & $\mathrm{n}$ & $\%$ \\
\hline 1. & Enough & 23 & 39,7 \\
2. & Less & 35 & 60,3 \\
\hline \multicolumn{2}{|c|}{ Total } & 58 & 100 \\
\hline
\end{tabular}

Table 5.

Distribution of the relationship between the provision of Personal Protective Equipment (PPE) with the incidence of work stress in health Workers in handling Covid-19 at Kandai Health Center

\begin{tabular}{|c|c|c|c|c|c|c|c|c|c|}
\hline \multirow{3}{*}{ No } & \multirow{3}{*}{$\begin{array}{c}\text { Provision of } \\
\text { PPE }\end{array}$} & \multicolumn{4}{|c|}{ Work Stress } & \multirow{2}{*}{\multicolumn{2}{|c|}{ Total }} & \multirow{3}{*}{$\mathrm{X}^{2}$ Count } & \multirow{3}{*}{$\mathrm{P}$ - value } \\
\hline & & \multicolumn{2}{|c|}{$\begin{array}{l}\text { Don`t } \\
\text { Stress }\end{array}$} & \multicolumn{2}{|c|}{ Stress } & & & & \\
\hline & & $\mathrm{n}$ & $\%$ & $\mathrm{n}$ & $\%$ & $\mathrm{n}$ & $\%$ & & \\
\hline 1 & Enough & 9 & 39,1 & 14 & 60,9 & 23 & 100 & \multirow{3}{*}{18,322} & \multirow{3}{*}{0,000} \\
\hline 2 & Less & 32 & 91,4 & 3 & 8,6 & 35 & 100 & & \\
\hline & Amount & 41 & 70,7 & 17 & 29,3 & 58 & 100 & & \\
\hline
\end{tabular}

\section{DISCUSSION}

The availability of complete personal protective equipment in a workplace is not a guarantee for every worker who wears it, this is influenced by several factors which become the reasons for them to use personal protective equipment. As for the factors that influence the behavior of using personal protective equipment on nurses during work, according to Lawrence Green, 1980 [3] behavior is influenced by 3 factors, namely predisposing factors, including knowledge, attitudes, actions, cultural systems, and education level. Enabling factors include the availability of facilities and infrastructure that support health services and reinforcing factors including attitudes of health workers, and regulations / policies [4].
Based on the results of statistical tests using Chi-Square, the value of $\mathrm{X} 2$ is calculated (18.322)> X2 table (3.841), thus there is a relationship between the provision of Personal Protective Equipment (PPE) and the incidence of work stress on health workers in handling Covid-19 at Kandai health center.

The results of this study indicate that out of 58 respondents, 9 people $(39.1 \%)$ stated that the provision of PPE was in the low category but not stressed, while 14 people $(60.9 \%)$ experienced stress in the provision of PPE which was categorized as lacking.

It is also known that out of 58 respondents, 32 people $(91.4 \%)$ stated that the provision of PPE was in the sufficient and not stressful category, but in the provision of PPE which was categorized as 
sufficient there were 3 people $(8.6 \%)$ who experienced stress.

This study is in line with the research of Idayanti (2008) [5], which states that there is a significant influence between the availability of facilities and the use of PPE.

Personal protective equipment is a tool that must be used when doing work that allows work accidents or occupational diseases to occur. So, every health worker, in terms of labor, wants to work safely, healthily and safely. One form of providing protection to workers against potential hazards and hazard factors in the workplace, the public health center provides Personal Protective Equipment for all workers for free during the Covid-19 pandemic. This is in accordance with Law No. 1 of 1970 concerning Work Safety, article 14 sub c, which states that the provision of free all personal protective equipment required for workers is under their leadership

\section{CONCLUSION}

Based on the results of the study, it can be concluded that there is a relationship between the provision of personal protective equipment (PPE) and the incidence of work stress among officers.

\section{REFERENCES}

1. S. CD, Keselamatan dan Kesehatan Kerja, Yogyakarta: Gosyen Publishing, 2014.

2. V. F.M, "Kondisi Garda Terdepan Indonesia Perangi Covid-19, Minimnya APD Dokter Spesialis," https://www.kompas.com/tren/read/2020/ 04/06/072000165/kondisi-gardaterdepan-indonesia-perangi-covid-19minimnya-apd-dan-dokter, indonesia, 2020.

3. L. Green, Health Education: A Diagnosis Approach, The John Hopkins University: Mayfield Publishing Co, 1980.
4. S. Notoatmodjo, Promosi Kesehatan dan Ilmu Perilaku, Jakarta: Rineka Cipta, 2007.

5. Idayanti, Hubungan Pengetahuan dan Sikap Perawat terhadap Penerapan SOP Teknik menyuntik dalam Upaya Pencegahan Infeksi di RSUD Pekanbaru, Medan: Tesis USU Medan, 2008. 